\title{
Hungarian War Aims During WWI: Between Expansionism and Separatism
}

\author{
Aliaksandr PIAHANAU \\ Беларускі дзяржаўны ўніверсітэт, гістарычны факультэт, кафедра гісторыі паўдневых і заходніх славян \\ Belarusian State University, Faculty of History, Department of Southern and Western Slav's History \\ Vul. Chyrvonaarmejskaja 6, 220030 Minsk, Belarus \\ Université Paris Diderot - Paris 7, Laboratoire "Identités - Cultures - Territoires » \\ University Paris Diderot - Paris 7, Laboratory « Identities - Cultures - Territories » \\ 8, Rue Albert Einstein, 75205 Paris cedex 13, France \\ piahanau@gmail.com
}

One of the central elements of modern Hungarian national identity - the so-called "Trianon trauma" - is directly related to the events of the Great War 1914-1918. The war ended by a drastic reduction of the Hungarian territory (from $325,000 \mathrm{~km}^{2}$ to 93,000 ) and as a consequence, the formation of large ethnic Magyar communities on the near border regions (around 3 millions). Despite this, the problem of Hungary's role in World War I and her strategic objectives remain on the periphery of historical introspection. This article is aimed to briefly cover the strategic objectives of Hungary in 1914-1918, mainly focusing on their territorial aspects. It argues that the maximalist territorial requirements of Hungary in WWI included the attachment of Serbia and Western Wallachia, more moderate ones indicated the joining of Bosnia-Herzegovina and Dalmatia. The minimum objectives were to retain the pre-war borders of Hungary, even at the cost of separation from Austria.

Roman Holec suggested in his 2011 essay that the studies of the Hungarian war aims had fallen into oblivion. He considers that this derives from the Hungarian culture of perception of WWI. The local historiography denies the Hungarian responsibility for the war beginning in July 1914 and thus it sees the "unjust» Trianon Treaty of 1920 as an «absurd» punition. Indeed, some Hungarian historians have stated that the Budapest government and parliament did not have any major influence on the foreign policy of the Habsburg Empire. ${ }^{1}$ On the contrary, R. Holec argues that Magyar politicians not only had an important role in the foreign policy decision-making of the Dual Monarchy, but also supported the declaration of war to Serbia in 1914 and, during the war, elaborated numerous projects for territorial enlargement of Hungary. ${ }^{2}$ The thesis about influential and expansionist character of Hungarian war planning has been recently reaffirmed by Benjamin Marvin Fried monograph's on the Austro-Hungarian war aims in the Balkans. ${ }^{3}$

\footnotetext{
1 For example, see: Mária ORMOS, Magyarország a két világháború korában, Debrecen 1998, 10-11.

2 Roman HOLEC, Trianon ako plač nad rozliatym mliekom a Uhorsko ako obet vojny (Globálne záujmy a vojnové ciele Uhorska), in: Zrod nové Evropy, Jindřich DEJMEK (ed.), Praha 2011, 89-112.

3 Marvin Benjamin FRIED, Austro-Hungarian War Aims in the Balkans during World War I, London $2014,320$.
} 


\section{The Hungarian factor in the foreign policy of the Dual monarchy}

The reforms in 1867 divided the Habsburg Empire into two legally equal parts - the Austrian Empire (Cisleithania) and the Kingdom of Hungary (Transleithania). Even though diplomacy remained a common subject (together with war and finance) and was orchestrated from the Ballhausplatz palace in Vienna, the Magyar factor played an increasing role in the Ministry of Foreign Affairs of Austria-Hungary (abbreviated as MdÄ). Transleithanians systematically held leading positions in the Balhausplatz and in the summer of 1914 they headed the Embassies of Austria-Hungary in Germany, Italy, Russia, France, Japan, and, in general, accounted for $37 \%$ of senior functionaries and $44 \%$ of diplomats in the $\mathrm{MdÄ} .{ }^{4}$

The growing Hungarian weight in the Monarchy's foreign policy relied on the internal development of Transleithania. Advances in economy and communication as well as the progress in the magyarization of the kingdom's multiethnic population (the number of Magyars had increased from 45 to $54 \%$ or from 6 to 10 million in 1880-1910) created a lot of optimism about the future role of Hungary. Dezső Bánffy, her Prime Minister in 1895-1899, forecasted in 1902 that the Habsburg Empire soon could be reformed into Hungary-Austria. ${ }^{5}$

On the background of this promising development, an idea about a special imperial mission for the Magyardom and its civilizing qualities started to flourish. This way of thinking was largely popularized by social scientists and publicists (Benjámin Kállay, Pál Hoitsy and Rezső Havass). First of all, they advocated the complete Magyarization of the Kingdom's population and afterwards the extension of Hungarian political, economic and cultural influence into the Balkans and the Adriatic. The radical manifestation of these imperialistic ideas became the turanist movement, which gained special popularity in 1914-1918. Its supporters believed that the Magyars, historically originated from Asia, had to strengthen links with other «Turan» peoples. Turanism got the sympathy of the elites and politicians such as István Tisza (Prime Minister in 1911-1917), Mihály Károlyi (PM in 1918-1919), Miklós Bánffy (foreign minister in 1921-1922) and especially Pál Teleki (PM in 1920-1921 and 1939-1941) attended the meetings of the Turanist Club in Budapest. ${ }^{6}$ During WWI, turanists issued a series of informal expansionist projects, for example, to annex and magyarise Serbia, Montenegro, Bulgaria and Bessarabia or to create Hungarian colonies in Africa. ${ }^{7}$

With the commencement of WWI, the political weight of Hungary in the Dual Empire grew. The long-serving Hungarian PM István Tisza not only started to lead the international negotiations, but also assisted in making his close supporter István Burián Minister of Foreign Affairs in 1915. ${ }^{8}$ Burián held this position until December 1916, and later on he was recalled. So, for the second time Burián lead the Habsburg diplomacy from April to

4 William D. GODSEY, Aristocratic redoubt. The Austro-Hungarian Foreign Office on the eve of the First World War, Purdue 1999, 128-129.

5 Ignác ROMSICS, Trianonská mierová zmluva, Bratislava 2006, 28.

6 Balázs ABLONCZY, Pál Teleki (1879-1941). The life of a controversial Hungarian politician, New York $2005,29$.

7 Ignác ROMSICS, A magyar birodalmi gondola, in: Múltról a mának, Budapest 2004, 121-158.

8 Iván BERTÉNY, Tisza István és az első Világhábórú, in: Mitoszok, legendák, tévhitek a 20. századi magyar történelemről, Ignác ROMSICS (ed.), Budapest 2005, 80. 
October 1918. Shortly before the collapse of the Monarchy, Burián was replaced by another Hungarian politician - Gyula Andrassy Jr.

The turanist programs were determined to end WWI by large territorial annexations. Meanwhile, the official standpoint of Budapest was much less expressive, depending on positions of other stakeholders. As B. M. Fried argues, the war plans of the Dual Monarchy were the products of discussions between the Emperor, the Common Ministerial Council (three Common Ministers plus the Austrian and Hungarian PMs) and the Military High Command. At the center of this decision-making process, Fried puts the BallhauspaltzMilitary-Hungarian triangle. ${ }^{9}$

It seems that during WWI, the strategic objectives of Austria-Hungary were flexible and easily modified according to the situation on the fronts and on the international scene. The fear of the emergence of a Great Serbia (supported by Russia) was the original cause of the war for the Monarchy. However, the global escalation of the conflict brought the pure Balkan motives of war on a wider range of international relations. This menaced the Habsburg Empire by grave territorial loses or even dissolution. The war could have different ends with all types of shades from a triumphal victory to a disastrous defeat. These perspectives gave birth to maximalist and minimalist war programs. As it will be shown later, in case of success, the Hungarian political circles desired to dominate the Balkans and to annex territories in Serbia and Romania. More moderate projects involved the redistribution of the old territories of the Habsburg Empire - the joining of Bosnia-Herzegovina (which was under the Austro-Hungarian condominium since 1908) and Austrian Dalmatia to Hungary. With a less successful state of affairs, Budapest thought to advocate the pre-war borders. In case of difficulties, as a radical way of ensuring the territorial integrity of the Kingdom, the Hungarian politicians even envisaged severance with Austria, declaration of independence and the conclusion of a separate peace treaty with the Entente.

\section{The Serbian question during the war and Hungary}

Serbia and her pan-Yugoslavian ambitions were at the heart of the Balkan policy of the Dual Monarchy. The southern Slav question significantly metamorphosed during WWI: in 1914, it was an external problem for the Monarchy; by 1918, it was acknowledged as a Hungarian problem. ${ }^{10}$ First of all, Budapest was confronted with Serbian aspiration to unite the Southern Slavs. It challenged the Hungarian rule in Vojvodina and Croatia-Slavonia as well as her pretentions over Bosnia-Herzegovina and Dalmatia. On the other hand, successful Austro-Hungarian territorial advances into the Balkans and in Russian Poland could lead to the growth of Slavic population inside the Monarchy and changes of her ethno-political balance. That perspective, allegedly, threatened the Magyar influence in Transleithania and the whole Habsburg Empire. Thus, the Hungarian government faced a dilemma - how to increase its territories and security, without threatening Hungarian position in the Monarchy's architecture?

9 FRIED, 2.

10 Mark CORNWALL, The Habsburg Elite and the Southern Slav Question, 1914-1918, in: A living anachronism? European Diplomacy and the Habsburg Monarchy: Festschift für Francois Roy Bridge zum 70. Geburtstag, Lothar HÖBELT - Thomas G. OTTE (eds.), Wien 2010, 269. 
At first, Budapest strove to keep the Austro-Hungarian status quo and the dualist equality. Basically, Hungarians wished to uphold the Monarchy's frontiers without considerable changes. Thus, when the Common Ministerial Council discussed the measures to be taken against Serbia on July 19, 1914, Hungarian PM I. Tisza persuaded the ruling organ of the Monarchy to refrain from the elimination of Serbia or its annexation as war aims. Tisza did not want to tighten Russia's reaction and, on the other hand, not to increase the share of the Southern Slavic population of the Habsburg Empire. The main opponent to Tisza was Franz Conrad von Hötzendorf, the Chief of the Austro-Hungarian General Staff. Franz Conrad pressed to annex Serbia and, this way, to destroy the "Yugoslav Piedmont»" ${ }^{11}$. However, Tisza's position was adopted by the Council and remained unchanged until 1916.

Nevertheless, after the pan-European escalation of the war, by the end of 1914, Tisza agreed to annex Belgrade and the Negotin district to Hungary, what could create a common frontier with Bulgaria. ${ }^{12}$ Later, after the Austro-Hungarian occupation of Serbia and Montenegro at the end of 1915, the attitude of Tisza towards the future of Serbia became more rigid. Contrary to Franz Conrad, who continued to propose large annexations in the Western Balkans, Tisza supported the accession of Northwestern Serbia to Hungary and its colonization by Magyars. Cut from the Adriatic, Montenegro and the remainder of Serbia (without Kosovo and Macedonia) had to become dependent territories of AustriaHungary. ${ }^{13}$

On 7 January 1916 the Common Ministerial Council discussed the Monarchy's position on Serbia, Montenegro and Albania. Still opposed to the annexationist plans of Franz Conrad, Tisza suggested attaching the Serbian region of Mačva to Hungary. Foreign Minister István Burián, who similarly to Tisza declared himself a defender of Hungarian interests, offered to enlarge the Monarchy by annexing Montenegro. Both Tisza and Burián also pushed forward a project of "Great Albania», which would include ethnic Albanian territories of Montenegro and Serbia. By building an «independent» Albania under the Austro-Hungarian protectorate, Burián wanted to improve the Monarchy's security in the Otranto Straits. Finally, the Crown Council adopted the Hungarian view on Albania. Yet, there was no clear decision on Serbia and Montenegro, except the supposition that if any Serbian territory was to be attached to the Monarchy, it would go to Hungary. ${ }^{14}$

The Serbian question remained the point of discord between Hungarian politicians. For example, Gyula Andrassy Jr., according to his memoires, supported the "correction» of the Serbian boundaries in favor of Austria-Hungary (and the protection of its dominance in the Danube basin and the Bay of Kotor) and Bulgaria. ${ }^{15}$ In March 1917, István Bethlen (PM of Hungary in 1921-1931) openly persuaded the Parliament that the only way to pacify Serbia was to make it part of Hungary and to give it autonomy together with Croatia and BosniaHerzegovina. ${ }^{16}$ However, Serbia was a too important piece of secret peace talks with the

11 HOLEC, 90-91; CORNWALL, 2010, 243.

12 CORNWALL, 2010, 247

13 CORNWALL, 2010, 254; Joseph KERNER, Austro-Hungarian War Aims in the winter of 1915-1916 as Revealed by Secret Documents, in: The Journal of International Relations, 10, 1920, 4, 463, 469.

14 FRIED, 133-135.

15 Gyula ANDRASSY Jr., Diplomacy and the War, London 1921, 163-165.

16 Bethlen István gróf beszédei és irásai. Budapest 1933, 125. 
Entente Powers that the Habsburg Empire did not dare to decide alone the Serbian fate. Thus, until the autumn of 1918, the Austro-Hungarian intentions regarding Serbia remained unclear, apart from the decision, made in the spring of 1917, to assist in changing the royal dynasty in Belgrade, to correct the borders and to make Serbia an economic satellite. ${ }^{17}$

\section{The territorial threats against Hungary and the intensification of Hungarian separatism (1914-1915)}

Geopolitical phobias explain the fluctuations of I. Tisza during the crisis of July 1914. In case of a war, Austria-Hungary had to beware not only for her southern frontiers, but also to keep watch on her Eastern neighbors - Russia and Romania. Furthermore, internal ethnic and social problems concerned the Habsburg elites.

The possibility to use Habsburg territories as a war-prize was discussed by the Entente from the very beginning of WWI. Petrograd holds the decisive voice in this regard. In September 1914, Russian Foreign Minister Sergei Sazonov indicated the British and French Ambassadors its views on the war aims regarding Austria-Hungary. First, Russia claimed Galicia and Silesia. Second, Sazonov proposed to give Bosnia-Herzegovina and Dalmatia to Serbia. Third, in the remainder of the Monarchy, Sazonov thought to create a third full subject - Bohemia, extended by Northern Hungary (Slovakia). Finally, he proposed to force Budapest to negotiate with Bucharest over Transylvania. ${ }^{18}$ Independently, the Russian General Staff considered expedient to attach Hungarian Máramaros (in Romanian Maramureș) county (Máramaros vármegye) ${ }^{19}$ to Russia. ${ }^{20}$

Serbian war aims, set in autumn 1914 and amended in 1916, contemplated the unification of southern Slavs (whose territorial claims extended along the line Graz - the Drava river Arad) and the compression of Hungary to Magyar ethnic regions. ${ }^{21}$ Romania thought about Bukovina and Transylvania. Since late summer of 1914, the Entente had urgently been proposing Transylvania to Romanians. ${ }^{22}$ Finally, the secret Bucharest Treaty in August 1916 bounded the Entente to recognize the Romanian territorial demands up to the Tisa River. Besides those external territorial threats, Austria-Hungarian dualism faced internal pressure. In this respect, the Czecho-Slovak movement became a significant danger. Emigrated Czech leaders (Tomáš G. Masaryk and Edvard Beneš) claimed an independent Bohemia (maybe with a Russian king), including Moravia-Silesia and Northern and Western Hungary. In the North of Hungary, Czechs demanded drawing of their frontiers from Pozsony (in German

17 Mark CORNWALL, 2010, 258; Ignác ROMSICS, Magyarország története XX. században. Budapest 2010, 104. 18 А. Л. ПОПОВ (подг. к печати), Международные отношения в эпоху империализма. Документы из архивов царского и Временного правительств. 1878-1917 (hereinafter referred only as МОЭИ. ДАЦВП). Ser. 3, $1914-1917$. Vol. 6, Part 1 (5 августа 1914-13 января 1915), Москва 1935, 247-249.

19 In 1919, the southern part of the county with its seat became a part of Romania and the northern part of the county became a part of Czechoslovakia.

20 Ф. О. НОТОВИЧ (подг. к печати), МОЭИ. ДАЦВП, S. 3. 1914-1917, Vol. 7, Part 1(14 января-23 мая 1915). Москва $1935,277-278$.

21 ROMSICS, 2006, 39; Miklós LOJKO (ed.), British policy on Hungary, 1918-1919. A Documentary Sourcebook, London 1995, 3-5.

22 А. Л. ПОПОВ, МОЭИ. ДАЦВП, S. 3. 1914-1917. Vol. 6, Part 1, 15. 
known as Preßburg, today Bratislava in Slovakia) to Kassa (today Košice in Slovakia) and Ungvár (today Ужгород in Ukraine, also known as Užhorod in Czech). ${ }^{23}$ By the end of WWI, Czechoslovak ambitions also extended over Subcarpathian Ruthenia. ${ }^{24}$

The Hungarian government took different measures to protect the Kingdom's integrity. Besides mobilization of 3 million of soldiers from Transleithania, Budapest tried to keep pro-Hungarian attitudes in still neutral Bucharest and Rome. Thus, already since August 1914, Budapest had been trying to gain the favor of Bucharest through supporting the attachment of Russian Bessarabia and Eastern Serbia to Romania. ${ }^{25}$ In the summer of 1915, I. Tisza inclined the Ballhausplatz to buy up Romanian harvest and even to cede Bukovina to Romania. ${ }^{26}$

The last radical way to insure the territorial integrity of Hungary was her break off with the Quadruple Alliance and even with Austria. Already in December 1914, through the diplomatic channels of the Entente, the rumor began to spread that Hungary, in order to save Transylvania, could start separate peace negotiations. ${ }^{27}$ Soon after that, in January 1915, Great Britain received first peace feelers from Budapest. A Magyar aristocrat, Pál Szapáry, unofficially contacted the British ambassador to Rome and suggested a separate peace between Britain and Hungary. ${ }^{28}$ On 21 January 1915, London informed Petrograd that a representative of the Hungarian opposition contacted the British government in order to conclude a separate peace with Hungary. Apparently, Hungary was ready to declare its independence and remain attached to Austria only through a personal union. Furthermore, Budapest was prepared to make peace with the Entente on the condition of Hungarian territorial integrity. In addition, Budapest was eager to support the transfer of Austrian Bukovina to Romania. Consulting Russians in this matter, Edward Grey, the British Secretary of State for Foreign Affairs, mentioned that this project contradicted to hopes, which were given to Romania. Probably, these «hopes» suggested that the Entente had promised Transylvania to Bucharest. Thus, Grey planned to indifferently answer that the declaration of independence was part of Hungarian internal politics. ${ }^{29}$ In its response to London on 23 January 1915, the Russian MFA stated that the Entente was not able to guarantee Hungary her integrity given the promises made to Bucharest and a Russian need to count with Slavic aspirations of liberation from the Magyar yoke. Despite these considerations, Russians thought that the Hungarian attempts of rapprochement should not be cooled down. Thus, Sazonov suggested to answer to the Hungarian representative that the Entente supported the wish of Hungary to proclaim independence and once this

23 А. Л. ПОПОВ (подг. к печати), МОЭИ. ДАЦВП, S. 3 1914-1917, Vol. 6, Part 2 (5 августа 1914-13 января 1915), Москва 1935, 268-269.

24 Jindřich DEJMEK (ed.), Československo na pařížské mírové konferenci, 1918-1920. Vol. I, Praha 2001, 52-55. 25 А. Л. ПОПОВ, МОЭИ. ДАЦВП, S. 3. 1914-1917. Vol. 6, Part 1, 169-172.

26 Gróf Tisza István összes munkái (hereinafter referred only as GTIÖM, S. 4), Vol. IV, Budapest 1927, 12-13, 35-37.

27 А. Л. ПОПОВ, МОЭИ. ДАЦВП, S. 3. 1914-1917. Vol. 6, Part 2, 233, 237-238.

28 Mark CORNWALL, Great Britain and the Splintering of Greater Hungary, 1914-1918, in: British-Hungarian Relations since 1848, Laszlo PETER - Martyn RADY (eds.), London 2004, 103-122; Ates USLU, «Nous sommes les amis de l'Entente». Le comte Mihály Károlyi dans les années de la Grande Guerre, in: Öt kontinens, 2007,5 , 266. 29 Ф. О. НОтОвич, 73-74. 
independence declared, the Entente would listen to Hungarian proposals. ${ }^{30}$

Trying to influence Romania through third countries, Budapest especially stood for the rapprochement with Italy and Bulgaria. In December 1914, Gy. Andrássy Jr., in order to reduce conflicts between Rome and Vienna, offered to hand over some Austrian regions to Italy. ${ }^{31}$ Also, I. Tisza recommended to offer Serbian Negotin to Bulgarians, ${ }^{32}$ which was later increased by Vardar Macedonia. In May 1916, I. Tisza already suggested to Bulgarians that the 1913 Bucharest peace could be revised. ${ }^{33}$ Attempts to approach Greece were made as well. In September, 1915 I. Tisza advised to tell the Greeks that on the condition of maintaining neutrality, they would get Lake Doiran and a free hand in southern Albania. Otherwise, Tisza suggested intimidating Greece with the loss of Thessaloniki. ${ }^{34}$

The idea of a separate peace with Hungary again started to circulate in the summer of 1915 after Rome stood on the side of the Entente. In the beginning of 1915, the president of the Hungarian independentist party, Mihály Károlyi, initiated secret negotiations with Italy. According to the memoires of Károlyi, on 15 March 1915, his messenger, the Orthodox priest János Török, met for the first time the Italian Minister of Foreign Affairs, Sidney Sonnino. Török persuaded Sonnino that an independent Hungary could serve the Italian interests and would have no territorial aspirations in the Balkans. In April, Török, through Italian mediation, established a contact with the British ambassador to Rome, James Rennell Rodd. However, on 23 May 1915, Italy declared war on Austria-Hungary. Despite this, Török and Sonnino met again soon after. This time, Sonnino declared that in case of the dismissal of I. Tisza in Budapest, Italy would agree to leave to Hungary her Adriatic encalve port in Fiume. Also, Sonnino was ready to press Romanians to minimize their claims in Transylvania. Meanwhile, Károlyi did not keep in secret these negotiations from the Emperor, Tisza and Burian ${ }^{35}$. The idea of peace with Hungary was neither dumped off in Petrograd in the summer of 1915. So, in June 1915, Italy and Russia assumed that the claims of Serbia to Croatia should be held back, in order not to disrupt the possibility of a separate retreat of Hungary from the war. ${ }^{36}$

\section{The Polish question and Hungarian claims to Bosnia-Herzegovina and Dalmatia (1915-1916)}

One of the central political issues during WWI was the Polish cause. The fate of territories with Polish populations, divided between Germany, Austria-Hungary and Russia, was a topic of passionate debates within the Central Powers and the Entente. Both blocks tried

30 Ф. О. НОТОВИЧ, 88-89.

31 ANDRASSY, 125-127.

32 GTIÖM, S. 4, Vol. IV, Budapest 1927, 20.

33 GTIÖM, S. 4, Vol. V, Budapest 1933, 168-171.

34 GTIÖM, S. 4, Vol. IV, Budapest 1927, 173-174.

35 Mihály KÁROLYI, Hit, illúziók nelkül, Budapest 1978, 86-88.

36 Игорь КРЮЧКОВ, Россия и проблема будущего Австро-Венгрии в годы Первой мировой войны, in: Чичеринские чтения. Россия и мир после Первой мировой войны: материалы международной научн. конф. 11-12 ноября 2008 г., Тамбов 2009, 38-41; Е. А. АДАМОВИЧ (подг. к печати), МОЭИ. ДАЦВП. Ser. 3, 1914-1917, Vol. 8, Part 1 (24 мая-16 октября 1915), Москва 1935, 359. 
to play «the Polish card» against the enemy. Comparing to the Balkans, where the Dual Monarchy could feel herself relatively free in her expansion, she had to better coordinate her policy in Poland with Germany. Moreover, two dynasties, the Hohenzollerns and the Habsburgs, showed their interests in attaching new Polish lands to their Empires. Hungary, who was not directly affected by this question, was interested in such a solution, which will better fit her interests.

The Habsburg plans to make Poland part of Cisleithania, also called the Austro-Polish solution, legitimized Magyar requests for a compensation of the enlarged power of Vienna. The most straightforward option of such compensation was the attachment of BosniaHerzegovina and Dalmatia to Hungary. Besides its strategic and historical reasons, the attention of Budapest to these two Slavic parts was based on legal reasons. On the one side, since 1908, when Bosnia-Herzegovina was annexed from the Ottoman Empire, her status was limited by the interim formulation of a joint Austro-Hungarian management. On the other hand, the claims to Austrian Dalmatia came from the Hungarian-Croatian compromise of 1868, which included the Zagreb requirements for the return of its «native» Dalmatian possessions. ${ }^{37}$

In the autumn of 1915, after improving the positions of the Central Powers on the fronts, the Hungarian separatism cooled down and intensive consultations on the Polish question unfolded between Budapest and Vienna. According to the memoires of Gyula Adrassy Jr. and Ottokar Czernin, PM I. Tisza saw three alternatives to deal with Poland: 1. to make it the possession of Austria as an autonomy (in this case Hungary was to receive BosniaHerzegovina and Dalmatia as a compensation); 2. to divide Congress Poland between the Dual Monarchy and Germany; 3. to return Poland to Russia. ${ }^{38}$ In his turn, Gy. Andrássy Jr. lobbied the annexation of Poland (consisting of Galicia and Congress Poland) to the Monarchy on an equal basis with Austria and Hungary. Other Hungarian politicians (Mihály Károlyi and Tivadar Batthyány) suggested creating an independent Poland. ${ }^{39}$

Indeed, the official Hungarian position on Poland was quite variable. On 2 October 1915, Tisza, preparing the meeting of the Crown Common Council, proposed his project on Poland to the government in Budapest. The governmental proceedings did not include the text of this project, but it seems that Tisza hoped that the Polish question would not need to be solved. He was even ready to give back Congress Poland to Russia in case of an «honest» peace. It was pointed out that Petrograd would more easily accept peace if Russians would still control their Polish possessions. This consideration was supplemented with the idea of passing Eastern Galicia to Russia. Nevertheless, Tisza clearly stated that if Poland united with Austria, Hungary should get Bosnia-Herzegovina and maybe Dalmatia. During the following discussion, ministers mentioned that that the extension of Austria would negatively affect the Hungarian parity and the national question in the Monarchy. Also, they disagreed with the idea to reform the Monarchy into a Trialist State with an equal status for Austria, Hungary and Poland. When the discussion turned to Bosnia-

37 HOLEC, 99.

38 ANDRASSY, 147-148; Оттокар ЧЕРНИН, В дни мировой войны. Мемуары министра иностранных дел АвстроВенгрии, Москва - Петроград 1923, 219-222.

39 ANDRASSY, 144-145; Andréa SCHMIDT, L'image de la Pologne en Hongrie au debut du XXe siecle (19141921), in: Bulletin de la Societé d'Histoire Moderne et Contemporaine, No. 3/4, 1996, 53-54. 
Herzegovina, Tisza declared that the solution of this «intolerable situation» laid in her attachment to Hungary. It is quite interesting that Tisza, notoriously known for his alleged fears of the increase of the Slavic population in Hungary, argued that if mostly Slavic BosniaHerzegovina went to Austria, it would create troubles for the Austrian Germans. Further, Tisza repeated that the acquisition of Dalmatia by Hungary could be a proper action if Vienna enlarged her power over Poland. The ban (viceroy) of Croatia, Iván Skerlecz, added that the Austro-Polish projects should take into account Hungarian territorial aspirations. He claimed that the joining of Bosnia-Herzegovina and Dalmatia was directly related to Croatia and could be successfully realized only if Serbia was destroyed. In conclusion, it was suggested that, with the unification of Croatia-Slavonia and Dalmatia, Zagreb would give Slavonia to Hungary as compensation. Finally, the government empowered Tisza to present his Polish project in Vienne. ${ }^{40}$ However, in practice, the solution of Polish question as well as the "Hungarian Transfer» of Bosnia-Herzegovina and Dalmatia was postponed until the very end of the war.

It appears that the standpoint of Budapest on the Polish question moved forward by the end of WWI. As Tisza was dismissed in June 1917, new PMs Moric Eszterházy (15 June-20 August 1917) and Sándor Wekerle (20 August 1917-30 October 1918) seemed to be more inclined towards Polish independence. Even Tisza, according to A. Schmidt, changed his mind and supported in a letter to Wekerle the creation of an independent Poland. ${ }^{41}$. The minister of neutral Swiss to Vienne, Ch. Boucart, wrote to Bern in November 1917 that the Hungarian government changed its old opposition to Trialism. Allegedly, a new belief appeared that the triple union of Austria, Hungary and Poland could be an advantage for Budapest, because the Poles, probably, would cooperate with the Magyars against the Austrians ${ }^{42}$.

\section{The impact of Romania's going to the war on the separatist and annexation moods in Hungary in 1917-1918}

On the eve of Romania's going to war with the Central bloc in August 1916, the separatist mood in Hungary intensified. On 17 July 1916, M. Károlyi founded the United Party of Independence and of 1848, which openly stood on the independentist, anti-German and pacifist platform. Secretly, M. Károlyi tried to obtain guarantees for the inviolability of Hungary's borders from the British and the French. ${ }^{43}$ The Ballhausplatz also tried to initiate peace negotiations. However, the peace initiative of I. Burián, contemplating the rectification of the borders in favor of Austria-Hungary in Serbia, Italy and Russia, the protectorate in Albania and independent Poland, was not acceptable to the Entente.

With Charles I of Habsburg ascending the thrown in November 1916, I. Burián was dismissed

40 Magyar Országos Levéltár (Hungarian National Archives, hereinafter referred only as MOL). Fond 27, Miniszterelnökség (Prime Ministry; hereinafter - ME), Minisztertanácsnak Jegyzőkönyve (Protocols to the Council of Ministers; hereinafter - MtJkv), 2 October 1915. No. 31, 43-58.

41 SCHMIDT, 53-56.

42 Jacques FREYMOND (ed.), Documents diplomatiques suisses, Vol. 6. 1914-1918, Bern 1981, 615-618.

43 USLU, 267-270. 
and Ottokar Czernin was appointed to lead the MdÄ. In early 1917, the Entente offered Austria-Hungary to reconcile, renouncing Transylvania, Bukovina, Bosnia-Herzegovina and Galicia. Arguing against the cessation of Transylvania, I. Tisza threatened O. Czernin that, if the Austrians tried to make peace at the expense of Hungary, independence would be proclaimed in Budapest. Otherwise, Czernin and Tisza agreed that the Dual Monarchy should continue the war if the Entente did not abandon her goals to split the Habsburg Empire. Also, Tisza noted that if Austria, seeking peace, ceded some territories, Hungary would not oppose, but Budapest should be consulted if a secession of Hungarian territories was discussed. ${ }^{44}$

At the same time, since 1917, Hungarians had been considering the projects of annexing the Romanian territories. In return, Tisza agreed to give up Bosnia-Herzegovina in favour of Vienna. On March 1917, at the Crown Council, he raised the question of the annexation of Western Wallachia to Hungary (to the west of the line connecting the south-eastern corner of Transylvania and Bucharest). In addition, Tisza proposed to transfer Moldova to Russia and to make a buffer state from the rest of Romania (with approximately 2-2.5 million people). However, the Austrians opposed the project of Tisza, who was soon dismissed by Charles I. 45

After the armistice of the Central Powers with Romania in Focsani on 9 December 1917, a new draft of the peace terms was worked out in Budapest. The Ministerial Council of Hungary discussed the peace making with Romania on 2 and 3 March 1918. The first day, the Minister of Trade, Józef Szterényi noted that Berlin wanted, by claiming Roman railways, port and oilfields, to put Bucharest under German dependence. This, Szterényi said, contradicted interests of Austria-Hungary, which could lose her markets (and political influence) in Romania. Also, a depleted Romania would be a danger for Hungary. Thus, Szterényi proposed to conduct a cautious and moderate policy during the peace negotiations with Bucharest. ${ }^{46}$ The next day, PM Sándor Wekerle told the ministers that Romania firstly agreed to change its borders and to hold the Romanian irredentism inside Hungary. ${ }^{47}$ According to Czernin, this time, Hungary hoped to annex the Romanian city of Turnu Severin, but these suggestions were cut short in Vienna. ${ }^{48}$ In the end, by the Treaty of Bucharest of 7 May 1918, Hungary achieved the annexation of 16 thousand $\mathrm{km}^{2}$ of Romanian territories, which strengthened its strategic position in the Carpathians. ${ }^{49}$

\section{Hungary's proclamation of independence and loss of territories (autumn 1918)}

In the final stage of the war, Hungarian politicians recovered influence in the MdÄ. In April 1918, I. Burián was re-appointed Minister of Foreign Affairs. The question of Bosnia-

44 ЧЕРНИН, 42-44.

45 HOLEC, 110; ЧЕРНИН, 227.

$46 \mathrm{MOL}$, K. 27, ME, MtJkv, 7 March 1918, No. 21, pp. 48-56.

47 MOL, K. 27, ME, MtJkv, 11 March 1918, No. 1, pp. 4.

48 ЧЕРНИН, 284.

49 ROMSICS, 2010, 106. 
Herzegovina and Dalmatia moved away from a standstill. By 1 October 1918, Charles I of Habsburg decided to hand Dalmatia and Bosnia-Herzegovina to Hungary, while Dalmatia would unite with Croatia. Discussing this matter, the Ministerial Council of Hungary suggested that if Dalmatia would unite with Croatia, then the Hungarian enclave port of Fiume should enlarge its territory from Susak to Kraljevica. ${ }^{50}$

The autumn of 1918 brought the collapse of the Quadruple Alliance. On 14 September 1918, Burián offered the Entente to set peace talks on the basis of Woodrow Wilson's «14 points» and of the federalization of Austria-Hungary. The Entente, however, refused. Then, Charles I put Gy. Andrassy Jr. in charge of the Ballhausplatz, who, having recognized the independence of Czechoslovakia and Yugoslavia, was able to establish the armistice with the Entente in Padua on 3 November 1918. Nevertheless, the days of the Dual Monarchy had passed. With the commencement of the Austrian federalization, the Wekerle government decided to declare Hungarian independence. ${ }^{51}$ Meanwhile, the revolution started in Budapest and the Emperor charged Mihály Károlyi to form a new governement in Budapest on 31 October 1918, which declared the independance of Hungary. Károlyi was ready to recognize the separation of Croatia and to provide autonomy to Romanians in Transylvania and Slovaks and Rusyns in Upper Hungary. However, even these concessions did not give Budapest any opportunity to hold back the expansionist pressure of Czechoslovakia, Romania and Serbia. Finally, the Trianon Peace Treaty of 1920 ceded to these States 70\% of the territories that used to be part of Hungary in 1914.

\begin{abstract}
The question of WWI aims of the Kingdom of Hungary, constituting a distinct State within the Habsburg Monarchy, remains almost unexplored. This paper tries to reduce this gap. First, it synthesizes the main features of Hungarian expansionist projects in 1914-1918. Second, it emphasizes the importance of war-time separatist scenarios, intending to ensure the territorial integrity of Hungary. This way, the Hungarian strategic thought during the war appears to have constantly balanced between perspectives of territorial enlargement (in case of a victory of Central Powers) and independence (in case of the Entente's success). Both alternatives had a common goal - to maximally secure the political freedom and territories of Hungary. The paper is based on the analysis and synthesis of available sources in Hungarian, Slovak, English, French and Russian (relevant historiography, published and archives documentation and memoirs).
\end{abstract}

\title{
Keywords
}

First World War, Hungary, war aims, Dual Monarchy, annexation, Treaty of Trianon, Central Europe, Balkans, István Tisza, Mihály Károlyi

\section{References}

$50 \mathrm{MOL}$, Fund 27, ME, MtJkv, 1 October 1918, No. 15, pp. 27-28.

$51 \mathrm{MOL}$, Fund 27, ME, MtJkv, 20 October 1918, No. 1, pp. 3-5. 
Magyar Országos Levéltár

Hungarian National Archives (MOL)

Fond 27, Miniszterelnökség, Minisztertanácsnak Jegyzőkönyve

ABLONCZY, Balázs: Pál Teleki (1879-1941). The life of a controversial Hungarian politician, New York 2005.

АДАМОВИЧ Е. А. (подг. к печати): Международные отношения в эпоху империализма. Документы из архивов царского и Временного правительств. 1878-1917. Ser. 3, 19141917, Vol. 8, Part 1 (24 мая-16 октября 1915), Москва 1935.

ANDRASSY Jr., Gyula: Diplomacy and the War, London 1921.

BERTÉNY, Iván: Tisza István és az első Világhábórú, in: Mitoszok, legendák, tévhitek a 20. századi magyar történelemről, ROMSICS, Ignác (ed.), Budapest 2005, 28-86.

Bethlen István gróf beszédei és irásai, Budapest 1933.

CORNWALL, Mark: Great Britain and the Splintering of Greater Hungary, 1914-1918, in: British-Hungarian Relations since 1848, PETER, Laszlo - RADY, Martyn (eds.), London 2004, 103-122.

CORNWALL, Mark: The Habsburg Elite and the Southern Slav Question, 1914-1918, in: A living anachronism? European Diplomacy and the Habsburg Monarchy: Festschift für Francois Roy Bridge zum 70. Geburtstag, HÖBELT, Lothar - OTTE, Thomas G. (eds.), Wien 2010, 236-270.

ЧЕРНИН, Оттокар: В дни мировой войны. Мемуары министра иностранных дел АвстроВенгрии, Москва - Петроград 1923.

DEJMEK, Jindřich (ed.): Československo na pařížské mírové konferenci, 1918-1920. Vol. I, Praha 2001.

FREYMOND, Jacques (ed.) : Documents diplomatiques suisses, Vol. 6. 1914-1918, Bern 1981.

FRIED, Marvin Benjamin: Austro-Hungarian War Aims in the Balkans during World War I, London 2014.

GODSEY, William D.: Aristocratic redoubt. The Austro-Hungarian Foreign Office on the eve of the First World War, Purdue 1999.

Gróf Tisza István összes munkái. Vol. IV, Budapest 1927.

HOLEC, Roman: Trianon ako plač nad rozliatym mliekom a Uhorsko ako obet' vojny (Globálne záujmy a vojnové ciele Uhorska), in: Zrod nové Evropy, Jindřich DEJMEK (ed.), Praha 2011, 89-112.

KÁROLYI, Mihály: Hit, illúziók nelkül, Budapest 1978.

KERNER, Joseph: Austro-Hungarian War Aims in the winter of 1915-1916 as Revealed by

Secret Documents, in: The Journal of International Relations, 10, 1920, 4, 444-470.

КРЮЧКОВ, Игорь: Россия и проблема будущего Австро-Венгрии в годы Первой мировой войны, in: Чичеринские чтения. Россия и мир после Первой мировой войны: материалы международной научн. конф. 11-12 ноября 2008 г., Тамбов 2009, 38-41.

LOJKO, Miklós (ed.): British policy on Hungary, 1918-1919. A Documentary Sourcebook, London 1995.

НОТОВИЧ Ф. О. (подг. к печати): Международные отношения в эпоху империализма. 
Документы из архивов царского и Временного правительств. 1878-1917, Ser. 3, 1914-1917, Vol. 7, Part 1 (14 января-23 мая 1915), Москва 1935.

ORMOS, Mária: Magyarország a két világháború korában, Debrecen 1998.

пОПОВ А. Л. (подг. к печати): Международные отношения в эпоху империализма. Документы из архивов царского и Временного правительств. 1878-1917. Ser. 3, 1914-1917. Vol. 6, Part 1 (5 августа 1914-13 января 1915), Москва 1935.

ПОПОВ А. Л. (подг. к печати), Международные отношения в эпоху империализма. Документы из архивов царского и Временного правительств. 1878-1917. Ser. 3, 1914-1917. Vol. 6, Part 2 (5 августа 1914-13 января 1915), Москва 1935.

ROMSICS, Ignác: A magyar birodalmi gondola, in: Múltról a mának, Budapest 2004, 121-158.

ROMSICS, Ignác: Trianonská mierová zmluva, Bratislava 2006.

ROMSICS, Ignác: Magyarország története XX. Században, Budapest 2010.

SCHMIDT, Andréa: L'image de la Pologne en Hongrie au debut du XX esiecle (1914-1921), in: Bulletin de la Societé d'Histoire Moderne et Contemporaine no. 3/4, 1996, 51-55.

USLU, Ates: «Nous sommes les amis de l'Entente». Le comte Mihály Károlyi dans les années de la Grande Guerre, in: Öt kontinens, 2007, 5, 263-287. 